\title{
Development of Renewable Material Hydrochar-Based CaAl Layered Double Hydroxide to Overcome Methyl Red Dyes Contaminant
}

\author{
Risfidian Mohadi', Novie Juleanti ${ }^{2,3}$, Neza Rahayu Palapa ${ }^{1,3}$, \\ Nurlisa Hidayati ${ }^{2}$, Aldes Lesbani ${ }^{1,3^{*}}$ \\ 1 Graduate School, Faculty of Mathematics and Natural Sciences, Sriwijaya University, Jl. Palembang- \\ Prabumulih, Km. 90-32, Ogan Ilir, South Sumatra, Indonesia \\ 2 Magister Programme, Faculty of Mathematics and Natural Sciences, Sriwijaya University, Jl. Padang Selasa \\ No. 524 llir Barat 1, Palembang, 30139, South Sumatra, Indonesia \\ ${ }^{3}$ Research Center of Inorganic Materials and Complexes, Faculty of Mathematics and Natural Sciences, \\ Universitas Sriwijaya, J.Padang Selasa Bukit Besar Palembang 30139, South Sumatera, Indonesia \\ * Corresponding author's e-mail: aldeslesbani@pps.unsri.ac.id
}

\begin{abstract}
The preparation of the $\mathrm{CaAl} / \mathrm{HC}$ composite was carried out with a supporting material in the form of hydrochar from duku skin. The success of the preparation was demonstrated by XRD, FT-IR, and BET analysis. The diffractogram of $\mathrm{CaAl} / \mathrm{HC}$ showed diffraction peaks at $2 \theta=10.16^{\circ}(003), 18.0^{\circ}(002), 20.15^{\circ}(006)$ and $65.4^{\circ}(110)$. The diffraction showed similarity to diffraction in $\mathrm{CaAl}$ and hydrochar double layer hydroxyl. The FT-IR spectrum of $\mathrm{CaAl} / \mathrm{HC}$ also showed similarity to the $\mathrm{CaAl} / \mathrm{HC}$ double layer hydroxyl at 3448,1635 , and $1381 \mathrm{~cm}^{-1}$. The characteristic spectrum of the hydrochar also appeared in $\mathrm{CaAl} / \mathrm{HC}$ at 20.15. BET analysis showed an increase in the surface area of $\mathrm{CaAl} / \mathrm{HC}$ before modification of $11.842 \mathrm{~m}^{2} / \mathrm{g}$ and increased to $22.635 \mathrm{~m}^{2} / \mathrm{g}$ of CaAl$/ \mathrm{HC}$. The ability of $\mathrm{CaAl} / \mathrm{HC}$ as an adsorbent is determined through several parameters including selectivity, regeneration, isotherm, and thermodynamics. The results of dye selectivity showed that $\mathrm{CaAl} / \mathrm{HC}$ was more likely to absorb MR dyes in a mixture of dyes (DG, MO, PR, MR, CR, and DR). The regeneration results showed the ability of CaAl/ $\mathrm{HC}$ which lasted up to $73.26 \%$ in the fifth cycle.
\end{abstract}

Keywords: $\mathrm{Ca} / \mathrm{Al}$, layered double hydroxide, hydrochar, methyl red, selectivity.

\section{INTRODUCTION}

Dyes are one of the contaminants the presence of which is often found in the waste that pollutes the environment. They are widely used as the main ingredient in several industries such as paper, cosmetics, food, and textiles. Dyes are included in the group of unsaturated organic compounds with chromophore as a color carrier and auxochrome as a color binder in the fiber. Dyes are divided into cationic, such as malachite green (Palapa, Taher, et al. 2020), methylene blue (Dayanidhi et al. 2020), rhodamine B (Dayanidhi et al. 2020), etc. as well as anionic dyes which include, Congo red (Taher et al. 2020), direct green (Hashem, Ahmad, and Badawy 2016), methyl orange (Onder et al. 2020) and methyl red (Yuan et al. 2016). Methyl red $\left(\mathrm{C}_{13} \mathrm{H}_{15} \mathrm{~N}_{3} \mathrm{O}_{2}\right)$ is one of the most anionic dyes widely used dyes in industry. It is one of the dyes that contain azo $(\mathrm{N}=\mathrm{N})$ (Bazan-Wozniak and Pietrzak 2020) chromofor groups, making these color substances are difficult to degrade in the environment, toxic and mutagenic if they accumulate in the body (Karri et al. 2018). Increasing the need for color substances makes its use more uncontrollable so that it can cause negative impacts on the environment. For this reason, effective efforts are needed to overcome the problem.

Several studies claim that adsorption is an effective and efficient method of dealing with liquid waste (Milagres et al. 2017). The adsorption 
method is the process of binding an adsorbate on the surface of the adsorbent to form a layer (Pontes-Neto et al. 2019). The adsorption method was chosen because the process is simple, environmentally friendly, has low energy requirements, low cost, produces high quality effluent, and the adsorbent used has the potential to be regenerated (Oktriyanti et al. 2020). Several factors need to be considered in the adsorption method, such as $\mathrm{pH}$ conditions, adsorption time, temperature, and adsorbate concentration. Determination of these parameters needs to be performed to achieve the optimum ability of the adsorbent which produces high adsorption power. The choice of adsorbate is also an important factor in the adsorption process. Types of adsorbate that can be used in adsorption are porous and layered materials such as clay, activated carbon, bentonite, zeolite, hydrochar, and layered double hydroxide.

Layered double hydroxide (LDH) is an adsorbent material belonging to anionic clay with $\left[\mathrm{M}^{2+}{ }_{1-\mathrm{x}} \mathrm{M}^{3+}{ }_{\mathrm{x}-}(\mathrm{OH})_{2}\right]^{\mathrm{x}+}\left[\left(\mathrm{A}^{\mathrm{m}-}\right)_{\mathrm{x} / \mathrm{m}} \cdot \mathrm{nH}_{2} \mathrm{O}\right]^{\mathrm{x}}$ where $\mathrm{M}^{2+}$ and $\mathrm{M}^{3+}$ are divalent and trivalent cations, and Am- is charge balancing interlayer anion (Palapa et al. 2021). The advantages of LDH include flexible properties, good thermal stability, and a large enough surface area (Wijaya et al. 2021). On the basis of these advantages, it is possible for LDH to be modified so that its adsorption ability increases so that it is effective in overcoming contamination. The study of the adsorption ability of LDH has been carried out by (Palapa et al. 2021) using $\mathrm{CuCr}$ with a surface area of $4.58 \mathrm{~m}^{2} / \mathrm{g}$ that was applied as an adsorbent of the malachite green color with Qmax reaching $27.585 \mathrm{mg} / \mathrm{g}$. Other studies conducted by (Juleanti et al. 2021) involved the application of $\mathrm{LDH} \mathrm{CaAl}$ and $\mathrm{MgAl}$ to overcome a contamination of $\mathrm{Cr}(\mathrm{VI})$ heavy metal ions with adsorption capabilities each reaching 47.02 and $23.15 \mathrm{mg} / \mathrm{g}$. In his study, (Siregar et al. 2021) used LDH NiAl as Congo red adsorbent with adsorption capacity of $61.728 \mathrm{mg} / \mathrm{g}$.

Modification of LDH can be done by intercalation (Palapa et al. 2021) and impregnation (Wahab et al. 2019). Impregnation is a method that can yield products in the form of composites with an increased surface area value from the constituent materials, and allows for an increase in the adsorption ability. The development of LDH into composites can be done with a supporting material, one of which is biomass in the form of hydrochar. The hydrochar produced from the hydrothermal carbonization process has a sufficiently large surface area to become the right choice for use as a supporting material for LDH composites. The research on the use of LDH-hydrochar composites was carried out by (Luo et al. 2020) to prepare MgAl-hydrochar from sewage sludge for $\mathrm{Pb}$ (II) adsorption resulting in an adsorption capacity of $62.441 \mathrm{mg} / \mathrm{g}$. The MgAl-hydrochar composite was also prepared by (He et al. 2019) using the main ingredient in the form of tobacco stalk with capacities of $30.69,31.42$, and 41.16 $\mathrm{mg} / \mathrm{g}$ at different temperatures $(25,35 \text {, and } 45)^{\circ} \mathrm{C}$.

In this study, the preparation of the $\mathrm{CaAl} / \mathrm{HC}$ composites from $\mathrm{CaAl}$ layered double hydroxide and supporting material in the form of hydrochar (HC) from duku fruit peel (Lansium domesticum) was carried out. The success of the preparation was supported through XRD, FT-IR, BET, and SEM analysis. The prepared material was applied as a dye adsorbent. The main parameter that was determined was the selectivity of the dye mixture (DG, MO, PR, MR, CR, and DR), which was then followed by the selective dyestuff. Other parameters that are also determined include regeneration, isotherm and adsorption thermodynamics.

\section{MATERIAL AND METHODS}

The chemicals used in this experiment $\mathrm{Ca}\left(\mathrm{NO}_{3}\right)_{2} .4 \mathrm{H}_{2} \mathrm{O}$ (Merck, $236.15 \mathrm{~g} / \mathrm{mol}$ ), $\mathrm{Al}\left(\mathrm{NO}_{3}\right)_{2} \cdot 9 \mathrm{H}_{2} \mathrm{O}$ (Merck, $\left.375.13 \mathrm{~g} / \mathrm{mol}\right), \mathrm{Na}_{2} \mathrm{CO}_{3}$ (Merck, $105.88 \mathrm{~g} / \mathrm{mol}$ ), demineral water, $\mathrm{NaOH}$ (Merck, $40.00 \mathrm{~g} / \mathrm{mol}$ ), $\mathrm{HCl} 37 \%$ by MallinckrodtAR ${ }^{\circledR}, \mathrm{C}_{2} \mathrm{H}_{5} \mathrm{OH}$ (Avantor, 99\%), hydrochar prepared by duku peel, synthetic dyes: direct green (DG), methyl orange (MO), procion red (PR), methyl red (MR), congo red (CR), and direct red (DR). The material characterization was performed using an XRD Rigaku mini flex6000 . The concentration of the dye was analyzed using a UV-Visible Biobase BK-UV 1800PC spectrophotometer.

\section{Synthesis of layered double hydroxide material}

The $\mathrm{Ca} / \mathrm{Al}$ double layer hydroxy synthesis was carried out in several steps. The first step was to dissolve $\mathrm{Ca}\left(\mathrm{NO}_{3}\right)_{2} \cdot 4 \mathrm{H}_{2} \mathrm{O} 0.75 \mathrm{M}$ in a $100 \mathrm{~mL}$ volumetric flask with $100 \mathrm{~mL} 0.25 \mathrm{M} \mathrm{Al}\left(\mathrm{NO}_{3}\right)_{3} \cdot 9 \mathrm{H}_{2} \mathrm{O}$. The mixture was adjusted to $\mathrm{pH} 10$ with the addition of $2 \mathrm{M} \mathrm{NaOH}$ then stirred for 30 minutes. The mixture was stirred for 24 hours at a temperature 
of $65^{\circ} \mathrm{C}$ to produce a white precipitate. The white precipitate was then filtered with the help of a vacuum pump and then dried at $100{ }^{\circ} \mathrm{C}$ and the $\mathrm{Ca} / \mathrm{Al}$ double layer hydroxyl was obtained. The resulting layered double hydroxide was characterized using XRD, FT-IR, and BET analysis.

\section{Preparation of composite layered double hydroxide material}

The $\mathrm{CaAl} / \mathrm{HC}$ composite was prepared by making a $30 \mathrm{~mL}$ solution of $\mathrm{Ca}\left(\mathrm{NO}_{3}\right)_{2} \cdot 4 \mathrm{H}_{2} \mathrm{O} 0.75$ $\mathrm{M}$ and $0.25 \mathrm{M} \mathrm{Al}\left(\mathrm{NO}_{3}\right)_{3} \cdot 9 \mathrm{H}_{2} \mathrm{O}$. The mixture was stirred and $3 \mathrm{~g}$ of hydrochar was added, then adjusted to $\mathrm{pH} 10$ with the addition of $2 \mathrm{M} \mathrm{NaOH}$. Afterwards, the mixture was kept at $80{ }^{\circ} \mathrm{C}$ for 72 hours. The composites obtained were then characterized by XRD, FT-IR, and BET.

\section{Adsorption studies}

The adsorption ability of the adsorbent is determined through several parameters including selectivity, regeneration, isotherm, and thermodynamics. The selectivity of the adsorbent was carried out by mixing DG, MO, PR, MR, $\mathrm{CR}$, and DR dyes and stirred for 0-120 minutes and then the wavelength was measured using a
UV-Vis spectrophotometer. Selective dye (MR) is followed by a regeneration process to determine the adsorbent ability when used repeatedly. The regeneration process is carried out by adsorption and desorption processes using water with ultrasonic which is carried out for up to 5 cycles. Furthermore, the determination of the thermodynamic and isotherm parameters of adsorption was carried out by varying the adsorption temperature $(30,40,50 \text {, and } 60)^{\circ} \mathrm{C}$ and the concentration of the dye $(50,75,100,125$, and 150) $\mathrm{mg} / \mathrm{g}$. Absorbance was determined using a UV-Vis spectrophotometer.

\section{RESULT AND DISCUSSION}

$\mathrm{CaAl}$ layered double hydroxide synthesis and $\mathrm{CaAl} / \mathrm{HC}$ composite preparation were carried out using the coprecipitation method. One of the success parameters was observed based on the characterization of XRD analysis. The results of XRD characterization produce the data in the form of a diffractogram at a certain angle. The diffraction pattern of the $\mathrm{CaAl}$ layered double hydroxide in Figure 1 shows the diffraction at $2 \theta=10.18^{\circ}$ (003), $20.61^{\circ}(006), 55.17^{\circ}(113)$, and $56.24^{\circ}$ (110). On the basis of these data, the diffraction
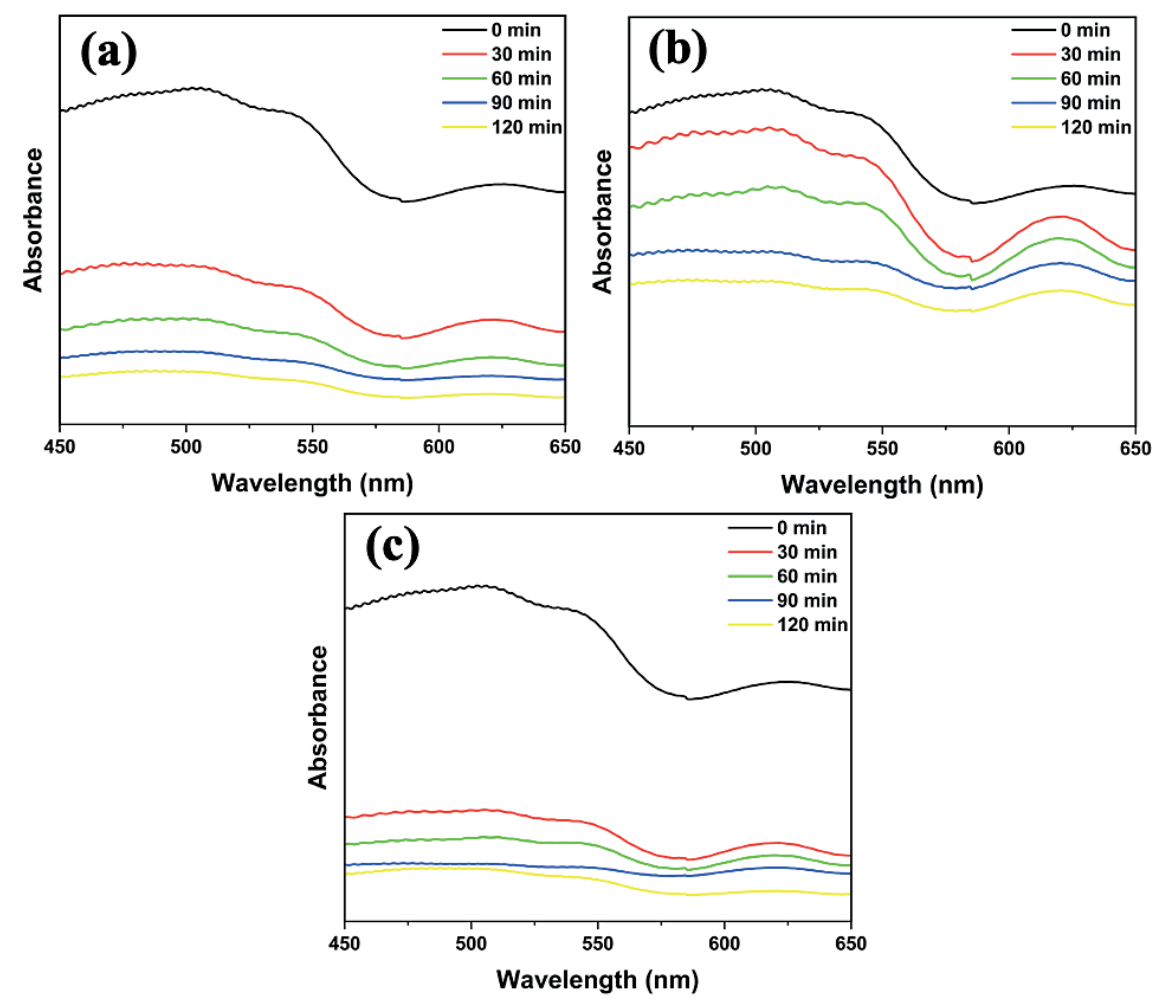

Figure 1. Diffraction of $\mathrm{CaAl}$ (a), $\mathrm{HC}(\mathrm{b}), \mathrm{CaAl} / \mathrm{HC}$ (c) 
peak of CaAl was in accordance with JCPDS No. 87-0493 which indicates that the CaAl synthesis has been successfully carried out.

According to (Palapa, Taher, et al. 2020), the diffraction peak around $10^{\circ}$ is one of the typical diffraction of materials with a layered structure. In contrast, the diffraction which is around $60^{\circ}$ indicates that there are anions in the interlayer material. Furthermore, the success of hydrochar preparation was supported by the presence of diffraction peaks at $2 \theta=22.47^{\circ}$ and $16.02^{\circ}$. This is in accordance with the research of (Normah et al. 2021) which explains that the hydrochar diffraction is around $22^{\circ}(002)$ which is a characteristic of cellulose and characteristic of hydrochar is at $15^{\circ}$ which is indicated as diffraction of amorphous material.

Composite diffraction (Fig. 1c) showed similarity to the layered double hydroxide and hydrochar. Figure 1c shows the diffraction peaks of $\mathrm{CaAl} / \mathrm{HC}$ at $2 \theta=10.16^{\circ}(003), 18.0^{\circ}(002)$, $20.15^{\circ}(006)$ and $65.4^{\circ}(110)$. The diffraction peaks (003), (006) and (110) are the diffraction peaks of CaAl, while (002) are the diffraction peaks of hydrochar. On the basis of these data, with the emergence of the main diffraction peaks from the precursor in the form of layered double hydroxide and hydrochar, the CaAl/HC composite has been successfully prepared.

The FT-IR analysis was also performed as the data to support the success of $\mathrm{CaAl} / \mathrm{HC}$ composite preparation. The results of the characterization of the $\mathrm{CaAl}$ are shown by the spectrum in Figure 2(a). The spectrum of CaAl showed the presence of vibrations at 3448,1635 , and $1381 \mathrm{~cm}^{-1}$. On the basis of (Palapa, Juleanti, et al. 2020), the vibrations found at 3448 and 1635 $\mathrm{cm}^{-1}$ indicate the presence of carbonyl and hydroxyl and $\mathrm{OH}$ groups. According to (Taher et al. 2020), the vibration of the nitrate originating from the base material for forming the layered double hydroxide is at $1381 \mathrm{~cm}^{-1}$. Meanwhile, the vibrations between $600-800 \mathrm{~cm}^{-1}$ indicate the vibrations from Metal-Oxygen.

Determination of the spectrum of the hydrochar presented in Figure 2(b) shows the presence of vibrations at 3448, 2931, 1573, 1442, and $1203 \mathrm{~cm}^{-1}$. Similar to the spectrum of the layered double hydroxide, the vibration of the hydroxyl group was at $3448 \mathrm{~cm}^{-1}$. Based on of (Badri et al. 2021), $2931 \mathrm{~cm}^{-1}$ is the vibration of the aliphatic - $\mathrm{CH}$ group of the alkane group. The vibration at $1573 \mathrm{~cm}^{-1}$ indicated the presence of a
$\mathrm{C}=\mathrm{O}$ group from the primary amide group. The intensity which tends to increase in $1442 \mathrm{~cm}^{-1}$ indicates a strain of the $\mathrm{C}=\mathrm{C}$ group originating from aromatic compounds. Meanwhile, the vibration at $1203 \mathrm{~cm}^{-1}$ indicates the presence of decomposed $\mathrm{Si}-\mathrm{O}-\mathrm{Si}$ groups. Figure 2(c) is the spectrum of the $\mathrm{CaAl} / \mathrm{HC}$ composite showing the presence of vibrations resembling layered double hydroxide and hydrochar. The vibrations are located at 3448 , 2931, 1635, 1381, and $1242 \mathrm{~cm}^{-1}$.

BET analysis was performed to determine the $\mathrm{N}_{2}$ adsorption-desorption pattern, surface area, pore volume and pore diameter. According to Moller and Pich (Siregar et al. 2021) the $\mathrm{N}_{2}$ adsorption-desorption pattern of $\mathrm{CaAl}$ in Figure 3 tends to follow type III. Type III characteristics are characterized by weak interactions between the adsorbate and adsorbent. The space available after the adsorption process on a single layer becomes very low. This causes a larger absorption value at a higher relative pressure. The isotherm pattern of HC resembling type IV indicates a mesoporous material that exhibits non-overlapping adsorption and desorption patterns. The $\mathrm{N}_{2}$ adsorption-desorption profile on the $\mathrm{CaAl} / \mathrm{HC}$ composite indicated the occurrence of $\mathrm{H} 4$ hysteresis. The hysteresis occurs in the adsorption-desorption process with a different mechanism on the adsorbent with pores that form gaps and is indicated by the adsorbent having a mesoporous size.

Table 1 shows that $\mathrm{CaAl}$ has a surface area of $9.621 \mathrm{~m}^{2} / \mathrm{g}$ with a pore volume of $0.027 \mathrm{~cm}^{3} / \mathrm{g}$ and a pore diameter of $3.169 \mathrm{~nm}$. The surface area of $\mathrm{HC}$ reaches $11.842 \mathrm{~m}^{2} / \mathrm{g}$ with a pore volume of

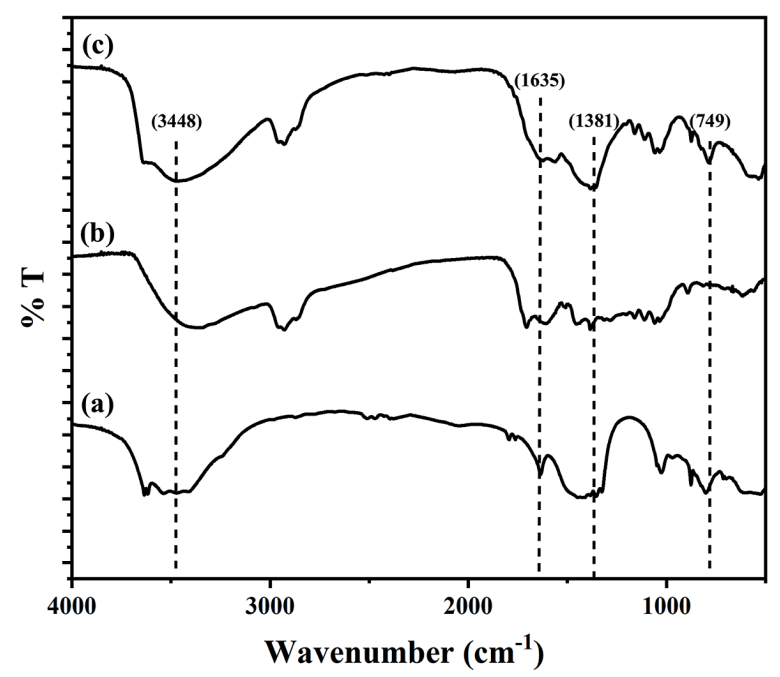

Figure 2. FT-IR spectra of $\mathrm{CaAl}$ (a), $\mathrm{HC}$ (b), $\mathrm{CaAl} / \mathrm{HC}$ (c) 


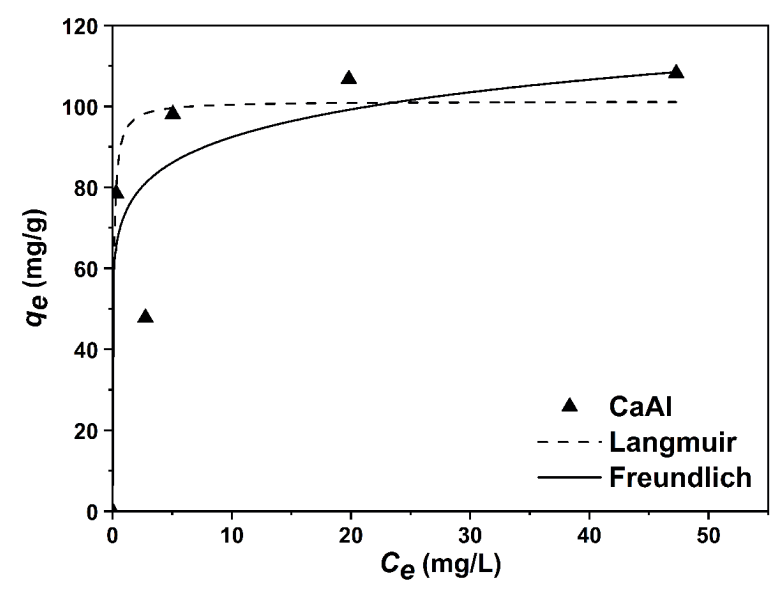

Figure 3. $\mathrm{N}_{2}$ adsorption-desorption pattern of $\mathrm{CaAl}(\mathrm{a}), \mathrm{HC}$ (b), and $\mathrm{CaAl} / \mathrm{HC}$ (c)

$0.026 \mathrm{~cm}^{3} / \mathrm{g}$ and a pore diameter of $17.059 \mathrm{~nm}$. The increase in surface area was seen in the $\mathrm{CaAl} /$ $\mathrm{HC}$ composite which reached $22.635 \mathrm{~m}^{2} / \mathrm{g}$ with a pore volume of $0.044 \mathrm{~cm}^{3} / \mathrm{g}$ and a pore diameter of $2.769 \mathrm{~nm}$. On the basis of these data, the increase in surface area that occurs in $\mathrm{CaAl}$ after being modified to $\mathrm{CaAl} / \mathrm{HC}$ indicates that the composite preparation process has been successfully carried out.

The surface morphology of the adsorbent was analyzed using SEM analysis which is presented in Figure 4. The CaAl layered double hydroxide shows a smooth surface morphology and agglomeration forms. The particle morphology pattern of the hydrochar adsorbent at a temperature of 200 ${ }^{\circ} \mathrm{C}$ which tends to be heterogeneous and has an irregular shape, this is due to the hydrothermal carbonization treatment given, causing the particles to split or commonly referred to as deaggregation. It can be seen that the surface of $\mathrm{CaAl} / \mathrm{HC}$ still has a smooth surface, but the agglomeration is reduced.

On the basis of the characterization above, $\mathrm{CaAl}, \mathrm{HC}$, and $\mathrm{CaAl} / \mathrm{HC}$ have the potential as adsorbents the ability of which is determined through the parameters of selectivity, regeneration, isotherm, and thermodynamics. Selectivity parameters were carried out by mixing anionic dyes which included DG, MO, PR, MR, CR, and

Table 1. Surface area analysis of $\mathrm{CaAl}, \mathrm{HC}$, and $\mathrm{CaAl} / \mathrm{HC}$

\begin{tabular}{|c|c|c|c|}
\hline Material & $\begin{array}{c}\text { Luas Permukaan } \\
\left(\mathrm{m}^{2} / \mathrm{g}\right)\end{array}$ & $\begin{array}{c}\text { Volume Pori } \\
\left(\mathrm{cm}^{3} / \mathrm{g}\right)\end{array}$ & $\begin{array}{c}\text { Diameter Pori } \\
(\mathrm{nm})\end{array}$ \\
\hline $\mathrm{CaAl}$ & 9.621 & 0.027 & 3.169 \\
\hline $\mathrm{HC}$ & 22.635 & 0.044 & 2.769 \\
\hline $\mathrm{CaAl} / \mathrm{HC}$ & 11.842 & 0.026 & 17.059 \\
\hline
\end{tabular}

DR and then carried out the adsorption process with time variations of $0,30,60,90,120$ and 150 minutes. The results of the scanning wavelength of the dye mixture are presented in Figure 5. The mixed dye adsorption process used the same concentration of $25 \mathrm{mg} / \mathrm{L}$ each.

Determination of adsorbent selectivity parameters $\mathrm{CaAl}, \mathrm{HC}$, and $\mathrm{CaAl} / \mathrm{HC}$ was carried out using a mixture of dyes, including DG, MO, $\mathrm{PR}, \mathrm{MR}, \mathrm{CR}$, and DR. The adsorption process was carried out with time variations ranging from $0,30,60,90$, and 120 minutes. The measurement of the wavelength of the dye mixture was carried out using a UV-Vis spectrophotometer $(450-650 \mathrm{~nm})$. Wavelength scan of the dye mixture produced the spectrum are presented in Figure 5. It can be seen that there is a decrease in absorbance for each $\mathrm{CaAl}, \mathrm{HC}$, and $\mathrm{CaAl} / \mathrm{HC}$ adsorbent with increasing time.

The scanned data for the mixed wavelengths of DG, MO, PR, MR, CR, and DR dyes are presented in Figure SL. It can be seen that there is a

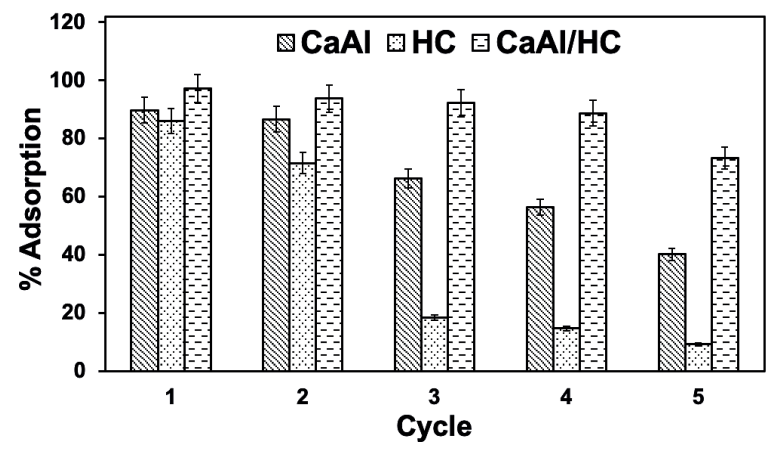

Figure 4. Morphology of $\mathrm{CaAl}(\mathrm{a})$, $\mathrm{HC}$ (b), and $\mathrm{CaAl} / \mathrm{HC}$ (c)

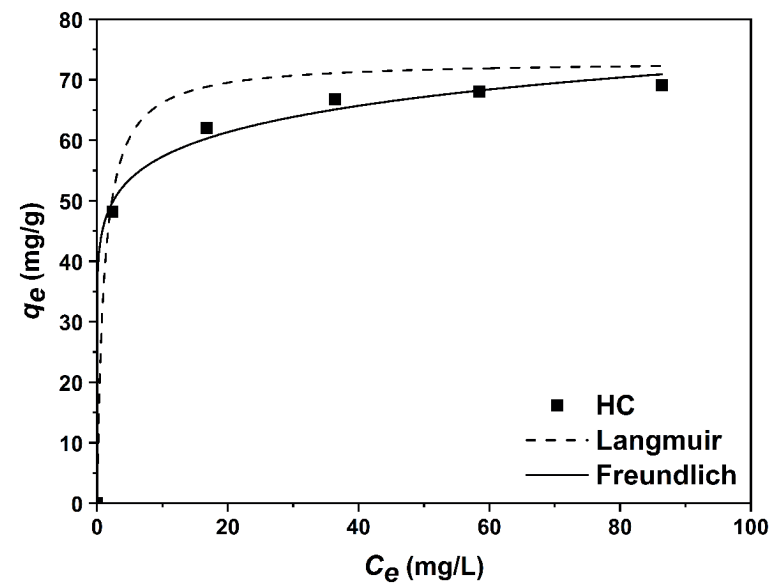

Figure 5. UV-Visible spectra of mixture dyes (DG, MO, PR, MR, CR, and DR) using $\mathrm{CaAl}$ (a), $\mathrm{HC}$ (b), and $\mathrm{CaAl} / \mathrm{HC}$ (c) 

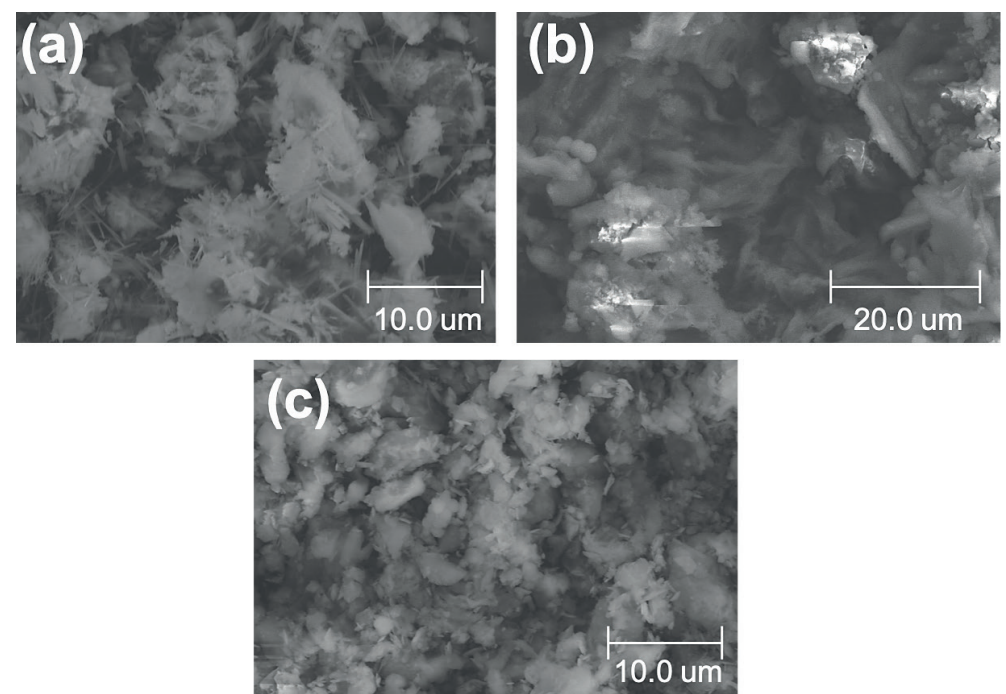

Figure 6. Regeneration process of $\mathrm{CaAl}$ (a), $\mathrm{HC}(\mathrm{b})$, and $\mathrm{CaAl} / \mathrm{HC}$ (c)

decrease in concentration with increasing contact time. Among the dye mixtures, MR showed a significant decrease in absorbance. The selectivity of $\mathrm{CaAl}$ to $\mathrm{MR}$ reached $8.87 \mathrm{mg} / \mathrm{g}$ at 120 minutes, $\mathrm{HC}$ reached $13.84 \mathrm{mg} / \mathrm{g}$, and $\mathrm{CaAl} / \mathrm{HC}$ showed an ability of $1.38 \mathrm{mg} / \mathrm{g}$. On the basis of this, selective dyestuff, MR was used for further determination of adsorption parameters.

The regeneration process was continued with the selective dye, MR, which is presented in Figure 6. regeneration process aims to determine the adsorbent ability that has been used repeatedly. The first stage of regeneration is adsorption on MR $1000 \mathrm{mg} / \mathrm{L}$; then, the desorption process is carried out to break the interaction between the adsorbent and the adsorbate through the water medium using ultrasonic. The working principle of ultrasonic is the propagation of high frequency waves in liquid media. The liquid will be propagated in the form of a sound medium with high-frequency ultrasonic waves that produce microscopic vibrations, so that the adsorbate that is strongly adsorbed can be separated more easily. This adsorption-desorption process was carried out for 5 cycles.

The first cycle of regeneration of $\mathrm{CaAl}$ showed an ability that reached $89.75 \%$, the second cycle lasted at $86.66 \%$ and decreased in the third cycle of $66.27 \%$ and $56.35 \%$ in the fourth cycle. The decline occurred until the fifth cycle which reached $40.11 \%$. Regeneration in $\mathrm{HC}$ reached $86.10 \%$ in the first cycle and decreased to $71.53 \%$. There was a significant decrease in the third cycle which reached $18.38 \%$ and $14.61 \%$ in the fourth cycle. The ability of HC continued to decline until the fifth cycle which reached $9.16 \%$. The regeneration of $\mathrm{CaAl} / \mathrm{HC}$ in Figure 6 shows the stability of the structure, where the first cycle reaches $97.22 \%$ and can last up to the third cycle which reaches $92.12 \%$. The decrease in absorbance ability was seen in the fourth cycle which reached $88.76 \%$ and the fifth cycle $73.26 \%$. The regeneration ability of $\mathrm{CaA} /$ $\mathrm{HC}$ remains above $50 \%$ so that $\mathrm{CaAl} / \mathrm{HC}$ has the potential to be used repeatedly.

Further adsorption parameters are determined by the Langmuir Freundlich isotherm model which is presented in Figure 7. The trend of Langmuir Freundlich adsorption isotherm model was determined based on the linear regression value $\left(\mathrm{R}^{2}\right)$. Figure A shows the tendency of $\mathrm{CaAl}$ towards the Freundlich isotherm model. The same thing is also seen in $\mathrm{HC}$ and $\mathrm{CaAl} / \mathrm{HC}$ which have a tendency towards the Freundlich isotherm model. The trend of the isotherm model in Figure 7 is also supported by the $\mathrm{R}^{2}$ value data in Table 2. CaAl, HC, and $\mathrm{CaAl} / \mathrm{HC}$ show the $\mathrm{R}^{2}$ values in the Freundlich isotherm model of $0.999,0.999$, and 0.995, respectively. On the other hand, the $\mathrm{R}^{2}$ values of the Langmuir $\mathrm{CaAl}, \mathrm{HC}$, and $\mathrm{CaAl} / \mathrm{HC}$ isotherm models are 0.995, 0.967, and 0.973, respectively. (Arabpour, Dan, and Hashemipour 2021) explained that the Freundlich isotherm model indicated that there was a physical adsorption process that occurred due to the weak bond between the adsorbent and the adsorbate involving Van der Waals interactions which allowed the adsorbate to move freely until the adsorption process formed a multilayer. 


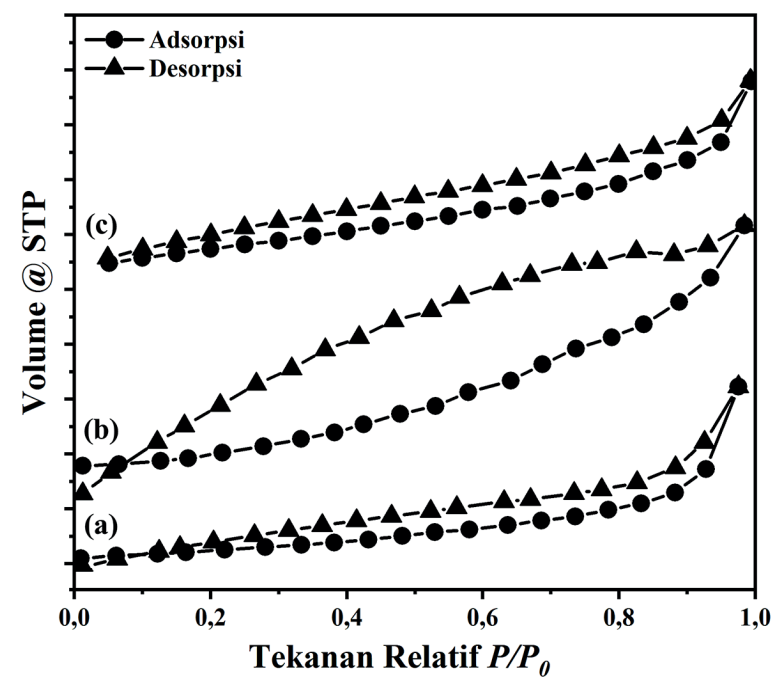

Figure 7. Langmuir-Freundlich isotherm model of $\mathrm{CaAl}(\mathrm{a}), \mathrm{HC}(\mathrm{b})$, and $\mathrm{CaAl} / \mathrm{HC}$ (c)

In addition to the value of $\mathrm{R}^{2}$, Table 2 also presents the value of adsorption ability (Qmax) of $\mathrm{CaAl}, \mathrm{HC}$, and $\mathrm{CaAl} / \mathrm{HC}$. The $\mathrm{CaAl}$ layered double hydroxide before the modification process had a Qmax of $116.279 \mathrm{mg} / \mathrm{g}$. HC as a composite support material has a Qmax value of $70.423 \mathrm{mg} / \mathrm{g}$. On the other hand, the $\mathrm{CaAl} / \mathrm{HC}$ composite has the largest Qmax reaching 121.951. The increase in Qmax after the modification process is supported by surface area using BET analysis in Table 1 . The surface area of $\mathrm{CaAl} / \mathrm{HC}$ which reaches 22.635 $\mathrm{m}^{2} / \mathrm{g}$ is the largest Qmax value between $\mathrm{CaAl}$ and $\mathrm{HC}$. On the basis of this, the increase in surface area affects the adsorption ability of the adsorbent.

After obtaining the isotherm data, the thermodynamic parameters were determined, including enthalpy $(\Delta \mathrm{H})$, entropy $(\Delta \mathrm{S})$, and Gibbs free energy $(\Delta G)$. The results of the determination of the adsorption energy of $\mathrm{CaAl}, \mathrm{HC}$, and $\mathrm{CaAl} / \mathrm{HC}$ on MR are presented in Table 3. The first parameter in thermodynamics in the form of $\mathrm{H}$ of $\mathrm{CaAl}, \mathrm{HC}$, and $\mathrm{CaAl} / \mathrm{HC}$ shows positive values in the range of 44.074-86.399 kJ/mol. According to (Juleanti et al. 2021), a positive $\Delta H$ indicates that the adsorption process is endothermic, where during the adsorption process it will absorb energy from the environment to the system to assist the interaction between the adsorbent and the adsorbate. According to Palapa et al. (2020), the $\Delta \mathrm{H}$ values which are in the range of $40-120 \mathrm{~kJ} / \mathrm{mol}$ indicate that the adsorption process takes place by chemisorption, whereas if it is outside this range, the adsorption process takes place by physisorption. On the basis of this statement, the adsorption process on MR using $\mathrm{CaAl}, \mathrm{HC}$, and $\mathrm{CaAl} / \mathrm{HC}$ is in the range of 40-120 kJ/mol; this explains that the adsorption process takes place by chemisorption.

Table 2. Isotherm parameter

\begin{tabular}{|c|c|c|c|c|c|c|}
\hline \multirow{3}{*}{ Materials } & \multicolumn{3}{|c|}{ Langmuir } & \multicolumn{3}{|c|}{ Freundlich } \\
\hline & \multirow{2}{*}{$k_{L}$} & Qmax & \multirow{2}{*}{$R^{2}$} & \multirow{2}{*}{$k_{F}$} & \multirow{2}{*}{$n$} & \multirow{2}{*}{$R^{2}$} \\
\hline & & $(\mathrm{mg} / \mathrm{g})$ & & & & \\
\hline CaAl & 0.720 & 116.279 & 0.995 & 106.758 & 41.373 & 0.999 \\
\hline $\mathrm{HC}$ & 0.592 & 70.423 & 0.967 & 44.906 & 9.662 & 0.999 \\
\hline $\mathrm{CaAl} / \mathrm{HC}$ & 0.720 & 121.951 & 0.973 & 86.159 & 15.129 & 0.995 \\
\hline
\end{tabular}

Table 3. Thermodynamic parameters

\begin{tabular}{|c|c|c|c|c|}
\hline Adsorbent & $\mathrm{T}(\mathrm{K})$ & $\Delta \mathrm{H}(\mathrm{kJ} / \mathrm{mol})$ & $\Delta \mathrm{S}(\mathrm{J} / \mathrm{mol} . \mathrm{K})$ & $\Delta \mathrm{G}(\mathrm{kJ} / \mathrm{mol})$ \\
\hline \multirow{4}{*}{$\mathrm{CaAl}$} & 303 & \multirow{4}{*}{48.165} & \multirow{4}{*}{0.162} & -0.966 \\
\hline & 313 & & & -2.588 \\
\hline & 323 & & & -4.209 \\
\hline & 333 & & & -5.831 \\
\hline \multirow{4}{*}{$\mathrm{HC}$} & 303 & \multirow{4}{*}{86.399} & \multirow{4}{*}{0.282} & 0.899 \\
\hline & 313 & & & -1.922 \\
\hline & 323 & & & -4.744 \\
\hline & 333 & & & -7.566 \\
\hline \multirow{4}{*}{$\mathrm{CaAl} / \mathrm{HC}$} & 303 & \multirow{4}{*}{44.074} & \multirow{4}{*}{0.146} & -0.190 \\
\hline & 313 & & & -1.651 \\
\hline & 323 & & & -3.111 \\
\hline & 333 & & & -4.572 \\
\hline
\end{tabular}


Table 4. Comparison of sorption capacities of various adsorbent for DG, MO, and PR

\begin{tabular}{|c|c|c|}
\hline \multirow{2}{*}{ Adsorbent } & Maximum & \multirow{2}{*}{ Ref } \\
\cline { 2 - 2 } & Capacity $\left(\mathrm{mg}^{-\mathrm{g}^{-1}}\right)$ & (Mahmoodi, Abdi, and Bastani 2014) \\
\hline ZFN-CTAB & 64.10 & (Hashem, Ahmad, and Badawy 2016) \\
\hline Cationized sawdust & 35.70 & (Hashem, Ahmad, and Badawy 2016) \\
\hline Natural sawdust & 9.30 & (Yu et al. 2018) \\
\hline Biochar-CMC & 39.47 & (Tran et al. 2020) \\
\hline${\text { Fe }{ }_{3} \mathrm{O}_{4} / \mathrm{C}}^{\mathrm{CoAl}-\mathrm{LDH}}$ & 38.03 & (Nazir et al. 2020) \\
\hline Magnetic geopolymer & 32.27 & (Hua et al. 2020) \\
\hline corncob & 25.46 & (Nazifa et al. 2018) \\
\hline CaAl & 2.86 & This work \\
\hline HC & 116.279 & \\
\hline CaAl/HC & 70.423 & \\
\hline
\end{tabular}

The $\Delta \mathrm{S}$ value of the MR adsorption process using $\mathrm{CaAl}, \mathrm{HC}$, and $\mathrm{CaAl} / \mathrm{HC}$ in Table 3 shows a positive value. According to (Badri et al. 2021), a positive value of $\Delta \mathrm{S}$ indicates the adsorption process involves a dissociative mechanism. Table 3 also shows a negative $\Delta \mathrm{G}$ value, which indicates that the adsorption process takes place spontaneously. In addition, it was seen that the $\Delta \mathrm{G}$ of $\mathrm{CaAl}, \mathrm{HC}$, and $\mathrm{CaAl} / \mathrm{HC}$ tended to decrease with increasing concentrations. This phenomenon explains that the adsorption process tends to be better carried out at high temperatures.

\section{CONCLUSIONS}

The $\mathrm{CaAl} / \mathrm{HC}$ composites were successfully prepared as evidenced by the main characteristics of CaAl layered double hydroxide and hydrochar through XRD, FT-IR, and BET analysis. CaAl/ $\mathrm{HC}$ was applied as adsorbent for methyl red dye. The ability of $\mathrm{CaAl} / \mathrm{HC}$ is shown through the data on the maximum adsorption capacity which reached $121.951 \mathrm{mg} / \mathrm{g}$. In addition, the adsorption ability of CaAl-HC was also shown through the regeneration results which persisted at $73.26 \%$ until the fifth cycle.

\section{Acknowledgements}

All authors thanks to the Laboratory of Inorganic Materials and Complexes of the Faculty of Mathematics and Natural Sciences, Sriwijaya University for support of this research.

\section{REFERENCES}

1. Arabpour A., Dan S., Hashemipour H. 2021. Preparation and Optimization of Novel Graphene Oxide and Adsorption Isotherm Study of Methylene Blue. Arabian Journal of Chemistry, 14(3), 103003. https://doi.org/10.1016/j.arabjc.2021.103003.

2. Badri A.F. et al. 2021. Mg-Al/Biochar Composite with Stable Structure for Malachite Green Adsorption from Aqueous Solutions. Bulletin of Chemical Reaction Engineering \& Catalysis, 16(1), 149-160.

3. Bazan-Wozniak A., Pietrzak R. 2020. Adsorption of Organic and Inorganic Pollutants on Activated Bio-Carbons Prepared by Chemical Activation of Residues of Supercritical Extraction of Raw Plants. Chemical Engineering Journal, 393, 124785.

4. Dayanidhi K., Vadivel P., Jothi S., Eusuff N.S. 2020. Facile Synthesis of Silver@Eggshell Nanocomposite: A Heterogeneous Catalyst for The Removal of Heavy Metal Ions, Toxic Dyes and Microbial Contaminants from Water. Journal of Environmental Management 271, 110962. https://doi.org/10.1016/j. jenvman.2020.110962

5. Hashem A., Ahmad F., Badawy S.M. 2016. Adsorption of Direct Green 26 onto Fix 3500 Treated Sawdust: Equilibrium, Kinetic and Isotherms. Desalination and Water Treatment, 57(28), 13334-13346.

6. He H. et al. 2019. Efficient Phosphate Removal from Wastewater by MgAl-LDHs Modified Hydrochar Derived from Tobacco Stalk. Bioresource Technology Reports, 8, 100348. https://doi.org/10.1016/j. biteb.2019.100348

7. Hua P. et al. 2020. Adsorption of Acid Green and Procion Red on a Magnetic Geopolymer Based Adsorbent: Experiments, Characterization and Theoretical Treatment. Chemical Engineering Journal, 383.

8. Juleanti N. et al. 2021. The Capability of BiocharBased $\mathrm{CaAl}$ and $\mathrm{MgAl}$ Composite Materials as 
Adsorbent for Removal Cr (VI) in Aqueous Solution. Science and Technology Indonesia, 6(3), 193-203.

9. Karri R.R., Tanzifi M., Yaraki M.T., Sahu J.N. 2018. Optimization and Modeling of Methyl Orange Adsorption onto Polyaniline Nano-Adsorbent through Response Surface Methodology and Differential Evolution Embedded Neural Network. Journal of Environmental Management 223, 517-529.

10. Luo X. et al. 2020. Hydrothermal Carbonization of Sewage Sludge and In-Situ Preparation of Hydrochar / MgAl-Layered Double Hydroxides Composites for Adsorption of $\mathrm{Pb}$ ( II ). Journal of Cleaner Production, 258, 120991. https://doi.org/10.1016/j. jclepro.2020.120991

11. Mahmoodi N.M., Jafar Abdi J., Bastani D. 2014. Direct Dyes Removal Using Modified Magnetic Ferrite Nanoparticle. Journal of Environmental Health Science and Engineering, 12(1), 1-10.

12. Milagres J.L. et al. 2017. Preparation and Evaluation of the Ca-Al Layered Double Hydroxide for Removal of Copper(II), Nickel(II), Zinc(II), Chromium(VI) and Phosphate from Aqueous Solutions. Journal of Environmental Chemical Engineering, 5(6), 5469-5480. http://dx.doi.org/10.1016/j. jece.2017.10.013.

13. Nazifa T.H. et al. 2018. Adsorption of Procion Red MX-5B and Crystal Violet Dyes from Aqueous Solution onto Corncob Activated Carbon. Journal of the Chinese Chemical Society, 65(2), 259-270.

14. Nazir M.A. et al. 2020. Surface Induced Growth of ZIF-67 at Co-Layered Double Hydroxide: Removal of Methylene Blue and Methyl Orange from Water. Applied Clay Science, 190, 105564. https:// doi.org/10.1016/j.clay.2020.105564.

15. Normah et al. 2021. Competitive Removal of Cationic Dye Using Nial-Ldh Modified with Hydrochar." Ecological Engineering and Environmental Technology, 22(4), 124-35.

16. Oktriyanti M., Palapa N.R., Mohadi R., Lesbani A. 2020. Effective Removal of Iron (II) from Aqueous Solution by Adsorption Using $\mathrm{Zn} / \mathrm{Cr}$ Layered Double Hydroxides Intercalated with Keggin Ion. Journal of Ecological Engineering, 21(5), 63-71.

17. Onder A., Ilgin P., Ozay H., Ozay O. 2020. Removal of Dye from Aqueous Medium with PH-Sensitive Poly[(2-(Acryloyloxy)Ethyl]Trimethylammonium Chloride-Co-1-Vinyl-2-Pyrrolidone] Cationic Hydrogel. Journal of Environmental Chemical Engineering, 8(5), 104436. https://doi.org/10.1016/j. jece. 2020.104436
18. Palapa N.R., Juleanti N., et al. 2020. Copper Aluminum Layered Double Hydroxide Modified by Biochar and Its Application as an Adsorbent for Procion Red. Journal of Water and Environment Technology, 18(6), 359-371.

19. Palapa N.R., Taher T., et al. 2020. CuAl LDH/Rice Husk Biochar Composite for Enhanced Adsorptive Removal of Cationic Dye from Aqueous Solution. Bulletin of Chemical Reaction Engineering \& Catalysis, 15(2), 525-537.

20. Palapa N.R., Taher T., Wijaya A., Lesbani A. 2021. Modification of $\mathrm{Cu} / \mathrm{Cr}$ Layered Double Hydroxide by Keggin Type Polyoxometalate as Adsorbent of Malachite Green from Aqueous Solution. Science and Technology Indonesia, 6(3), 209-217.

21. Pontes-Neto J.G. et al. 2019. Intercalation of Olanzapine into CaAl and NiAl Layered Double Hydroxides for Dissolution Rate Improvement: Synthesis, Characterization and in Vitro Toxicity. Journal of Drug Delivery Science and Technology, 52, 986996. https://doi.org/10.1016/j.jddst.2019.05.034.

22. Siregar P.M.S.B.N., et al. 2021. Structural Stability of Ni/Al Layered Double Hydroxide Supported on Graphite and Biochar Toward Adorption of Congo Red. Science and Technology Indonesia, 6(2), 85-95.

23. Taher T. et al. 2020. A Comparative Study on Azo Dyes Removal Behavior to $\mathrm{ZnAl}$ and $\mathrm{ZnCr} \mathrm{LDHs}$. 9, 106-114.

24. Tran T.V., et al.2020. RecyclableFe3O4@C Nanocomposite as Potential Adsorbent for a Wide Range of Organic Dyes and Simulated Hospital Effluents. Environmental Technology and Innovation, 20, 101122. https://doi.org/10.1016/j.eti.2020.101122

25. Wahab N., et al. 2019. Synthesis, Characterization, and Applications of Silk/Bentonite Clay Composite for Heavy Metal Removal From Aqueous Solution. Frontiers in Chemistry 7, 1-12.

26. Wijaya A., et al. 2021. Innovative Modified of $\mathrm{Cu}-$ $\mathrm{Al} / \mathrm{C}$ ( $\mathrm{C}=$ Biochar, Graphite ) Composites for Removal of Procion Red from Aqueous Solution, 6(4), 228-234.

27. Yu J., Zhang X., Wang D., Ping Li P. 2018. Adsorption of Methyl Orange Dye onto Biochar Adsorbent Prepared from Chicken Manure. Water Science and Technology, 77(5), 1303-1312.

28. Yuan Y., Yong X., Zhang H., Deng J. 2016. Biobased Microspheres Consisting of Poly(Trans-Anethole-CoMaleic Anhydride) Prepared by Precipitation Polymerization and Adsorption Performance. ACS Sustainable Chemistry and Engineering, 4(3), 1446-1453. 